\title{
General protocols based on evidences
}

\author{
Silvia Menendez-Cepero \\ Collaborator of the National Center for Scientific Research. Havana, Cuba.
}

\section{ABSTRACT}

\section{OPEN ACCESS}

\section{Citation}

Menendez-Cepero S. General protocols based on evidences [abstract]. Proceedings of the 5Th WFOT Meeting; $2016 \mathrm{Nov}$ 18-20; Mumbai, India. J Ozone Ther. 2018;2(2). doi: 10.7203/ jo3t.2.2.2018.11125

\section{Academic Editor}

Jose Baeza-Noci, School of Medicine, Valencia University, SPAIN

\section{Editor}

World Federation of Ozone Therapy, Bolgna, ITALY

\section{Received}

December 9, 2017

\section{Accepted}

December 10, 2017

\section{Published}

March 4, 2018

\section{Intellectual Property}

Silvia Menendez-Cepero.

This is an open access article distributed under the terms of the Creative Commons

Attribution License (CC BY 4.0), which permits unrestricted use, distribution, and reproduction in any medium, provided the original author and source are credited.

\section{Author Information}

silviamenendez@infomed.sld.cu
Ozone has been used as a therapeutical agent for the treatment of different diseases and beneficial effects have been observed. However, ozone biological effects remain controversial due to the scarce knowledge of its biochemical and pharmacodynamic mechanisms [1]. Taking into account that ozone therapy is gathering more interest, day by day, and it has been used in apparently nonrelated diseases with beneficial effects, the National Center for Scientific Research (Havana, Cuba) in collaboration with different research centers and health institutions have studied the ozone toxicology and its pharmacological actions as well as its biochemical mechanisms.

The most remarkable experiences, in preclinical and clinical studies, developed in Cuba during the last 30 years, in order to prove unequivocally ozone therapy validity, are presented in this lecture.

On the basis of the oxidant properties of ozone, we postulate that controlled ozone administration (named as ozone oxidative pre-/postconditioning mechanism) is able to promote a slight and transient oxidative stress which in turn re-establishes the signalling pathways which have been lost in pathological conditions, preserving the cellular redox balance (increasing antioxidant endogenous system), mitochondrial function as well as the regulation of transcription factors and the modulation of the immunological system [2]. It is evident that membrane-associated ozone peroxides, 4hydroxialkenals, superoxide anion, nitric oxide, among others, are going to play an important role in cellular signals as well as in the pathology of different diseases [2,3]. Regulation of these biomolecules by ozone preconditioning has been demonstrated in several preclinical and clinical studies as ischaemia-reperfusion phenomenom, parkinson, senile dementia, disk herniation, retinitis pigmentosa, ischemic cardiopathy, arterial insufficiencies, diabetes, osteoarthritis, asthma, vestibulocochlear syndrome, among others $[2,4]$. Nitric oxide modulation, as well as the increase in A1 adenosine receptors achieved with this therapy has an important role in brain blood flux, in the formation of memory, in the release of neurotransmitters and in the inflammatory processes $[5,6]$. Ozone therapy seems to induce a simultaneous resuscitation of functions that had gone wrong, reactivating and re-equilibrating physiological activities.

This lecture contributes to clarify the ozone mechanism of action and its different pharmacology effects. It is concluded that ozone therapy can be useful in the treatment of several diseases, either as adjuvant of ortodox medicine or taking part positively in those where conventional therapy has had no success, all this with a common purpose: to favour the patients and contribute to a better quality of life.

Keywords: ozone therapy, ozone oxidative preconditioning, antioxidant defense system, oxidative stress, cellular redox balance, nitric oxide, reactive oxygen species. 


\section{References:}

1. Bocci V. Scientific and medical aspects of ozone therapy. State of the art. Arch Med Res 2006;37:425-435.

2. Menendez S, Gonzalez R, Ledea OE, Hernandez F, Leon OS, Diaz M. Ozono. Aspectos básicos y aplicaciones clínicas. La Habana, Cuba: Editorial CENIC; 2008.

3. Leon OS, Menendez S, Calunga JL, Viebahn R. Ozone Oxidative Postconditioning reduces oxidative protein damage in patients with Disc Hernia. Neurological Research 2012;34(1):59-67.

4. Menendez S, Del-Cerro A, Alvarez T, Hernandez F. Application of Ozone Therapy in the Vestibulocochlear Syndrome. Reviews on Recent Clinical Trials. 2012;7:321-328.

5. Ajamieh HH, Menendez S, Martinez-Sanchez G, Candelario-Jalil E, Re L, Giuliani $A$, et al. Effects of ozone oxidative preconditioning on nitric oxide generation and cellular redox balance in a rat model of hepatic ischaemia-reperfusion. Liver Int. 2004;24:55-62.

6. Leon OS, Ajamieh HH, Berlanga J, Menendez S, Viebahn R, Re L, et al. Ozone oxidative preconditioning is mediated by $A 1$ adenosine receptors in a rat model of liver ischemia/reperfusion. Transpl Int. 2008;21:39-48 